\title{
Castro Alves y José Santos Chocano ${ }^{1}$
}

\author{
POR Bella JOzeF
}

Cada literatura tiene un poeta épico, que canló sus glorias, sus luchas y su naturaleza, su poeta. En Perú es José Santos Chocano, en Brasil, Castro Âlves. Pertenecen cronológicamente a dos escuelas distintas, a distintas épocas: cuando Chocano nace, Castro Alves había muerto. El baiano vivió en plena fase victorhuguesca; su asunto esencial fue la libertación de los esclavos y la República. Santos Chocano fue un americanista total: ya lo afirmó otro gran americanista, Silvio Julio. Pero, si son de escuelas distintas y Chocano es un modernista con vestigios románticos mientras Castro Alves es un romántico que se anticipó a la escuela parnasiana que después vendría podemos encontrar identidad entre los dos, no sólo de temperamento como de procedimientos estilísticos (etema yormab. Converso"

Este es el estudio que presentamos. Llevados inicialmente a acercarlos por sus temperamentos idénticos, hemos descubierto notables semejanzas y diferencias, buscando sacar las conclusiones que nos parezcan necesarias. Que este ensayo represente una contribución al estudio comparativo entre las dos figuras, representativas de dos naciones vigorosas y hermanas.

Castro Alves fue el más grande representante de la tercera generación romántica brasileña y surge en una época en la cual ya estaba formada una tradición literaria por obra de sus predecesores. No es, así, un fenómeno aparte en nuestra literatura. Cual-

1 Conferencia pronunciada en el Salón de Grados de la Universidad Nacional Mayor de San Marcos, durante el curso de Vacaciones de Post-Graduados; $y$ en el Instituto Cultural Peruano-Brasileño, en febrero de 1960. 
quiera de sus facetas puede ser confrontada con antecesores y contemporáneos. Los acontecimientos políticos estimulan a esta poesía, que internamente ya estaba madura. Pero Castro Alves a todos superó, aunque, poeta contradictorio, posea chispas de genio y recaídas.

Antonio de Castro Alves nació en Baia. Allí inició sus estudios y a los 16 años fue mandado a Recife para estudiar derecho. Cumplió un rápido destino: en seis años había ido a Recife, São Paulo, Baia. Río. Arrebataba a las muchedumbres, propagando la Abolición y la República; había amado y entonado los más suaves cantos de amor; había llevado a la escena su drama patriótico y había impreso su libro inmortal Espumas Flutuantes en 1870.

A fines de 1868 se hirió el pie en un accidente casual y el debilitamiento lo conduce a la tuberculosis, muriendo en 1871. Desde el 64, en una poesía llena de presentimiento, "Mocidade e morte", esperaba el momento final:. . Dentro em meu peito.

Um mal terrivel me devora a vida...

Fôra louco esperar! tria rajada

Sinto que do viver me extingue a lampa...

Resta-me agora por futuro- a terra,

Por glória nada, por amor-a campa...

En Espumas Flutuantes secmuestra el entusiasta por las grandes empresas libertadoras, fal dadp delcelima gracioso y sencillo de su felicidad. Sus grandes temas son las luchas por la independencia en Baia, la insurrección de los Palmares, el papel civilizador de la Imprenta. La campaña contra la esclavitud será enfocada en Os Escravos y $A$ cachoeira de Paulo Afonso.

Con el modernismo se adopta en Hispanoamérica una actitud estética que pretende liberar a la poesía de las "impurezas" de la vida cotidiana. En José Santos Chocano, el modernismo, (que es en realidad una suma de simbolismo, parnasianismo $\mathrm{y}$ romanticismo), no consiguió calmar el tumulto de su alma romántica, una "caótica fuerza sudamericana", como dijo Ventura García Calderón. Se inicia en el romanticismo de fines de siglo -en el romanticismo postrero hugoniano y su persistencia romántica se aprecia en Iras Santas, En la Aldea (1895). Azahares (1896), Selva Virgen (1897) y hasta en obras posteriores. Defiende también las causas nobles, pues decía que "antes que ser poeta... hay que ser hombre" (aunque después crea superado este momento y 
se considere poeta ante todo). Impresionado por Whitman, manifestó que

"Walt Whitman tiene el norte, pero yo tengo el sur", no transmitiendo un hondo mensaje intelectual como aquél.

Castro Alves se consideraba "un bravo soldado de la redención de la humanidad" y fue uno de los primeros abolicionistas a servicio de las causas nobles y generosas de su época. Goncalves Dias es considerado el cantor del indio y Castro Alves del negro esclavo y de los oprimidos. Con sus cantos heróicos en que llega a la entonación bíblica, conmovía a la juventud que lo escuchaba y lo seguía:

Senhor Deus dos desgraçados!

Dizei-me, vós, Senhor Deus!

Se é loucura.. . se é verdade

Tanto horror perante os céus?

Y apela para su tierra y para toda América:

.. Da etérea plaga

Levantai-vos heróis do Novo Mundo!

Andradal arranca êsse pendão dos ares!

Colombol fecha a porta dos teus mares!

Alberto de Oliveira decía que "con excepción de algunas estrofas camonianás no conozco en nuestra lengua otros versos tan vibrantes". En esta apóstrofa que continúa fresca, pura y resonante como cristal, después de tantas citas, sentimos una contención sorda de ciertos grandes diálogos de la poesía con el misterio del destino y el crítico Antônio Cândido lo compara a Villon.

Nostre Seigneur se tient tout coi,

Car au tancer il le perdroit.

Los jóvenes de su tiempo, en los cuales él creía y que llamaba "sol brilhante do céu da liberdade", han formado dos décadas después la generación de los libertadores.

Castro Alves no siguió solamente las corrientes de sensibilidad de su tiempo y en una época en la cual los motivos de arte eran una idealización del salvaje primitivo, impuso sus pensamientos a su pueblo. Para resolver el problema de la esclavitud apela para la revolución con la República. Los versos heroicos 
con hipérboles e imágenes audaces se mezclan con las notas de ternura por los esclavos. Son estos conceptos nuevos en su época.

$\mathrm{Su}$ lirismo, llamado por Afranio Peicoto, cósmico, emplea metáforas -relámpagos, que resumen cielos, mundos, auroras, crepúsculos:

Calcinado aos relâmpagos da glória.

Son frecuentes las alusiones a la amplitud, el infinito, la inmensidad, notándose en ambos poetas el empleo de substantivos y adjetivos semejantes e idénticos. Dirá Castro Alves:

Cúpula imensa de um sepulcro enorme...

o: Desperta o infinito...

Y Chocano: Cuando las carabelas voladoras

al tin trazaron sobre el mar sus huellas,

fueron rasgando por delante dellas

la inmensidad con sus tremantes proras.

De ahí las imágenes hiperbólicas, grandiosas:

Cabelos esparsos ao sopro dos ventos

Olhar desvairado, sinistro, fatal,

Dirieis estátua roçando nas nuvens

Pra qual a montanha se tez pedestal

... Dois infinitos

Ali se estreitam num abraço insano.

El peruano J. S. Chocano usa procedimientos semejantes cuando dice:

es un conjunto que se mueve con la armonía pintoresca

de un ajedrez que se jugase sobre un tablero colosal.

(La caravana del Sultón).

Su manía de grandiosidad hiperbólica es expresada también en números:

Tres millones de insectos

formaban una como rabiosa inarmonía.

Son ambos, usando una expresión del poeta Salazar Bondy "retóricos y detonantes" pero no siempre falsos. Hay una cierta 
embriaguez verbal, un desencadenar de metáforas, lenguaje fuerte, apostólico y vibrante, al cual se debe el gran poder de comunicabilidad.

La naturaleza aparece en ambos en toda su magia, belleza y misterioso encanto. Con gran vigor de sugestión, sin huir por veces a un pintoresquismo, ella vibra y palpita, a través de las imágenes, y personificaciones. En Castro Alves es el paisaje serianejo, en una fresca acuarela:

Era a hora em que a tarde se debruça

Lá da crista das serras mais remotas

de preferencia en el crepúsculo, cuando se acerca la noche, "a tenda azul de Deus", siempre "plácida y divina", "lánguida y sentida", "mansa y calma", frecuentemente comparada a los cabellos de su amada:

"As trevas rolam como as tranças negras

Como um negro e sombrio firmamento

Sõbre mim desenrola o teu cabelo

Lo que ve en la noche no es solamente la molicie y placidez, la colorea también.

\section{Dolcéliazur na profundez escura \\ Brilhava pa esirêla como um truto louro \\ Brinca o luar- dourada borboleta}

La noche aparece real, se dirige con calor y ternura a ella, personificando muchas veces los astros, el rayo de luna que juega $\circ$ el mismo crepúsculo que anuncia la noche:

..... Iam caindo

Dos dedos do crepúsculo os véus de sombra

Es una naturaleza que vive y palpita y Eça de Queiroz dijo: "He ahí en dos versos toda la poesía de los trópicos", refiriéndose a:

Às vêzes quando o sol nas matas virgens

As fogueiras das tardes acendla."

José Santos Chocano también posee un sentimiento penetrante de la naturaleza, en lo que es romántico todavía y lo que no 
se había dado en el romanticismo peruano. La expresa con luz, calor y color. Dió categoría poética al paisaje peruano, transmitiendo dinamismo a todo.

Copia el lago en sus vidrios palpitantes cuando se asoma en su contorno vago

○: Cada volcón levanta su figura, Cual si de pronto, ante la faz del cielo, suspendiesen el ángulo de un velo dos dedos invisibles de la altura.

en donde vemos elementos idénticos a los de Castro Alves en una cita anterior: "dedos" y "velo". Chocano, aún en su fase moderna, propiamente dicha, no se aleja de la búsqueda del paisaje americano. Esta tendencia, al lado de la búsqueda del espíritu americano, serć permanente en él. Varían los procedimientos. También la noche tiene colores para él:

Sobre el luto de la noche que envolvía la montaña una roja medialuna levantaba su cuchilla.

También personifica los elementos de la naturaleza humanizándola:

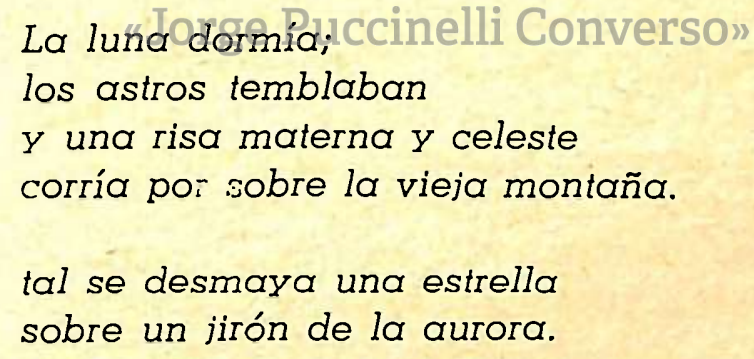

El mar, inspirador de poetas, por su grandiosidad, por su apariencia mutable, por su inmensidad, significando todo lo que es grande, infinito, es un elemento común a los dos poetas y les sugiere imágenes semejantes.

Para Castro Alves:

O mar se atira de bruços

com a barba pelo areal 
y para Chocano:

el mar tiene cabellos de rizada espuma y

...el mar, cual cabellera

de un filósolo anciano de la clásica Era

sacudía los bucles de sus olas.

Para Castro Alves:

o mar-corcel que espuma ao látego do vento

y Chocano da la misma idea de movimiento al río:

que galopa

como un titán que empuña la cola de un dragón.

En Santos Chocano:

porque así son, en la montaña andina,

el río una serpiente que camina

y el lago una serpiente que se enrosca.

En Castro Alves:

A meus pés a onda mansa

Por entre os juncos s'entrança

Bil comó una cobra afugir.'s

Castro Alves emplea el mar en comparaciones para dar idea de inmensidad:

Aquelas terrras tão grandes

Tão compridas como o mar

- el mismo cielo se compara al mar:

Ouço os astros cantar no mar do firmamento

Y el pecho de la amada es:

mar de amor onde vogam meus desejos.

Santos Chocano personifica el mar, refiriéndose a Núñez de Balboa:

...el mismo mar... te dió un abrazol

Ambos poseen un sentido plástico de la naturaleza, envolviéndola en el torbellino de la metáfora, empleando los más va- 
riados recursos expresionistas, en los cuales el lenguaje se liberta de la rutina para adecuarse al sentimiento individualista, intransferible.

Compárese los cuadros de una caravana y las imágenes visuales que sugiere en ambos:

Por la monótona llanura/ se va tendiendo largamente la caravana del sultán/ En la llanura hace un instante/ que hasta un millar/ de blancas tiendas se plegaron/ como en un haz/ a la manera de una banda/ de albas palomas que se lanzasen a volar... (Chocono)

De Tebas nas colunas derrocadas/ as cegonhas espiam debruçadas/ O horizonte sem fim.../ Onde branqueja a caravana errante/ $E$ o camelo monótono, arquejante/ que desce de Efraim... (Castro Alves).

Hemos visto, en relación al tema de la noche, que Castro Alves era un visual y auditivo. En sus poemas, "tudo é luz, aroma e murmúrio". En "A queimada", vemos los colores rojos del incendio

Eis súbito, da barra do ocidente, Doudo, rubro, yeloz, incandescente, O incêndio que acordout Letras

y oímos:

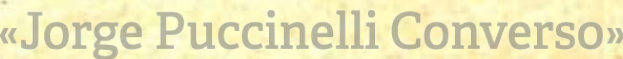

O estampido estupendo das queimadas

Se enrola de quebradas em quebradas Galopando no ar.

Antecede en esto a la poesía de Verlaine y los simbolistas. Es visual, como los parnasianos, aunque no frío e impasible como ellos.

También hay cruces de sensaciones en algunos poemas:

Ontem à tarde quando o sol morria

Larga harmonia embalsamava os ares

०:

Ao tíbio clarão da lua.

Hubiera llegado a la perfección formal, pues ya demuestra por veces el culto por la forma que será característica de la época posterior, disciplinando su verbalismo con arte. Se anticipa tam- 
bién en cuestiones estéticas a su época, verdadero trazo de unión entre las generaciones de Alvares de Azevedo y Fagundes Varela por un lado y la de Olavo Bilac y Alberto de Oliveira por otro.

En Chocano, que es de época posterior, es el procedimiento de las sinestesias muy empleado:

derramando la alegre frescura

que tiene el plateado sonido del agua

...las brisas en que viaja el lúbrico olor de la selva

En el rornanticismo brasileño se defrontan dos características: por un lado, el sentimiento nacionalista, la valorización de lo autóctono, del tema local, que es a su vez uno de los aspectos de la estética romántica. Por otro lado, el miraje de Europa y sus románticos Byron, Musset, Espronceda.

Castro Alves y José Santos Chocano toman el primer aspecto: Castro Alves fue un poeta brasileño, como Santos Chocano fue poeta peruano. Es sumamente importante este aspecto en ellos no por sí mismo, pero sí por lo transcendental Castro Alves fué uno de los precursores de nuestra independencia literaria que llevaría a una expresión propia y original. José de Álencar en la prosa y Castro Alves en la poesía son los precursores de un "brasileirismo" iniencional, significando con esto nuestra independencia literaria. Ya lo dijo Ändré Gide, que Cés nacionalizándose que una literatura toma dugarpen la humanidad yosignificación en el concierto del mundo". Lo universal y lo nacional no se contraponen, se complementan. Hay intercomunicación entre nación y universo, nacionalismo y universalismo. Y José Oiticica dijo que Castro Alves creó tres cosas que no existían en la poética nacional antes de él: el paisaje, el estilo y el tema social brasileño.

En el aspecto americano son varias las notas que los distinguen. Aunque Castro Alves cante el continente en su totalidad en "O livro e a América", no adivinó, como dijo el maestro Silvio Julio, el mundonovismo complejo e integral de que Santos Chocano tejió su filosofía estética. Chocano siempre buscó el tono continentalista para sus rimas impetuosas:

América es mi sola fuente de poesía y América es pujante, montañosa y radiante; tal en el verso mío se incrusta el consonante como en sortija pétrea firmísimo diamante. 
Al mismo tiempo exalta a América en conjunción de lo español $y$ lo indio:

Soy el cantor de América autóctono y salvaje mi lira tiene un alma, mi canto un ideal.

Mi verso no se mece colgado de un ramaje, Con un vaivén pausado de hamaca tropical...

El indianismo ha servido en Brasil no sólo como pasado mítico y legendario, como lo acentuó Antonio Cãndido, sino como pasado histórico, a la manera de la Edad Media. Leyenda e historia se han fundido en la poesía de Gonçalves Dias y más aún en la novela de Alencar, por el esfuerzo de suscitar un mundo poético digno del europeo. Chocano, con su Alma América marca el pleno retorno a los temas nativos en la poesía hispanoamericana. Tras los contados alegatos en favor del indio que periódicamente se dieron en la literatura hispanoamericana a lo largo del siglo XIX, sólo con la Revolución Mejicana de 1910 tomó cuerpo política y literariamente. Su primera página importante fue el poema "¿Quién sabe?" de Santos Chocano escrito en 1913.

Castro Alves, como lírico, tuvo sensibilidad, originalidad y llegaría a alcanzar la impecabilidad parnasiana; como épico, propagó la causa humanitaria de la esclavitud, precursor de muchas utopías liberales y Manuel Bandeira pudo decir que "fue la más grande fuerza verbal ar da inspiración Más generosa de toda la poesía brasileña".

De Santos Chocano, yo encuentro en común a Castro Alves la poderosa fuerza verbal, lo épico, los procedimientos estilísticos que traté de demostrar como formación de imágenes dotadas de plasticidad, comparaciones y metáforas y señalo, con Porras Barrenechea, las tres direcciones de su poesía: la épica, ungida de "emoción histórica, verbal y tribunicia"; la bucólica, donde expande su "vigoroso poder descriptivo y de gran sensitivo dominador de todas las percepciones de olor, color y sonido" y la autobiográfica. 